\title{
Available nutrients and some soil properties of El-Qasr soils, El-Dakhla Oasis, Egypt
}

\author{
Mahdy H. Hamed ${ }^{1}$, Mostafa Y. Khalafallh ${ }^{2}$ \\ ${ }^{1}$ Soil and Water Sci. Dept., Fac., of Agric., Assiut Univ., New Valley \\ ${ }^{2}$ Soil and Water Sci. Dept., Fac., of Agric., Al-Azhar Univ., Assiut
}

\begin{abstract}
Ten surface soil samples $(0-30 \mathrm{~cm})$ were collected from El-Qasr village, El-Dakhla Oasis, New Valley, Egypt to investigate some soil properties and nutrients availability. The results revealed that most of the soil texture varied clay loam to sandy clay loam. The mean values of bulk density (BD), soil $p H$, electric conductivity $(E C)$, saturation percentage $(S P)$, calcium carbonate $\left(\mathrm{CaCO}_{3}\right)$, cation exchangeable capacity $(\mathrm{CEC})$, organic matter $(O M)$, and sodium adsorption ratio (SAR) were $1.42 \mathrm{gcm}^{3}, 7.89,3.34 \mathrm{dSm}-1,52.10 \%, 7.46 \%, 28.08$ $\mathrm{cmol}(+) \mathrm{kg}^{-1}$, and 3.65 , respectively. The mean values of $\mathrm{N}, \quad P$, and $K$ were $99.37,31.32,121.93, \mathrm{mg} / \mathrm{kg}$, respectively. Meanwhile, the mean values of $\mathrm{Fe}, \mathrm{Mn}, \mathrm{Cu}$ and $\mathrm{Zn}$ were $27.39, \quad 18.38,0.48$, and $3.48 \mathrm{mgkg}^{-1}$, respectively. The correlations coefficient of NPK was strongly positively significant relationship with clay, OM, $C E C$, and $S A R$, but they negatively correlated with $\mathrm{pH}$, $\mathrm{EC}, \mathrm{CaCO}_{3}$. Meanwhile, $\mathrm{Fe}, \mathrm{Mn}$, and $\mathrm{Cu}$ were positively correlated with $\mathrm{EC}, \mathrm{CaCO}_{3}$, while they negatively correlated with clay, $p H, O M, C E C$, and SAR. Also, Zn was negatively correlated with clay, $p H, E C, O M$, and $\mathrm{CaCO}_{3}$, and it positively correlated with CEC and SAR.
\end{abstract}

Keywords-Available nutrients, soil physico-chemical properties, El-Qasr area, El-Dakhla Oasis.

\section{INTRODUCTION}

El-Dakhla Oasis is belongs to the New Valley governorate that is located at the middle of the Western Desert of Egypt between longitudes $28^{\circ} 2200^{\prime \prime}-29^{\circ} 30$ $00^{\prime \prime} \mathrm{E}$ and latitudes $25^{\circ} 2500^{\prime \prime}-25^{\circ} 5500^{\prime \prime} \mathrm{N}$ (Fig. 1). This area of El-Dakhla oasis has not conducted any studies to investigate the content of the available nutrients in their soils. El-Dakhla Oasis is the southern one in this cluster of depressions and represents an important feature in the Western Desert [11]. The general climate of ElDakhla oasis is lies within the extremely arid belt, with long hot summer and short warm winter, since the mean monthly minimum temperature values range from 4.30 to $9.90 \mathrm{C}^{\circ}$ in winter and from 28.50 to $32.30 \mathrm{C}^{\circ}$ in summer. The groundwater is the only water resource for all life activities ([12]. Soil fertility is one of the important factors controlling the crop yield. So, soil testing provides the information about the nutrient availability of the soil upon which fertilizer recommendation for maximizing crop yield. Nutrients available depend on soil $\mathrm{pH}$, organic matter content, and other physical-chemical properties [16]. Soil characterization in relation to the evaluation of fertility status of the soils of an area or region is an important aspect in the context of sustainable agriculture production. Soil variability is naturally caused by climate, topography, parent material, vegetation, time, and management practices [2]. Soil nutrients are essential for plant growth, development, and reproduction. So, if nutrients sunlight and water are present in sufficient amounts, plants can create all the compounds needed for typical development [13]. Macronutrients are commonly available to plants as exchangeable cations. These cations content an immediate source of nutrients for plants, but some insoluble sources may exist. Also, micronutrients are generally derived from parent materials, such as ferromagnesian minerals and basic igneous rocks [24]. The main objective of the current study is assessed to the availability of macro-micronutrients and some soil physical -chemical properties of El-Qasr area. These assessments will be helping us understanding the future scope of growth of plants in this region.

\section{MATERIALS AND METHODS}

Ten surface soil samples $(0-30 \mathrm{~cm})$ were collected from El-Qasr area in the western part of El-Dakhla oasis that is located between longitudes $28^{\circ} 42^{\prime \prime} 00-28^{\circ} 58^{\prime \prime} 00 \mathrm{E}$ and latitudes $25^{\circ} 40^{\prime \prime} 00-25^{\circ} 44^{\prime \prime} 00 \mathrm{~N}$ (Fig.1). The main crops grown on this area are parley, alfalfa, date balm and wheat plants. The collected soil samples were air-dried, crushed and sieved through a 2-mm sieve and kept for physic-chemical analysis. Particles-size distribution and the electrical conductivity of the soil samples were performed using the method of [19]. Soil organic matter content was determined using the dichromate oxidation method [19]. Soil calcium carbonate was estimated using the calcimeter method according to [23]. Soil reaction $\mathrm{pH}$ was determined in saturated soil paste suspension by a gears electrode [22]. Soil salinity (EC) was measured in 1:2.5 of soil and water extract using conductivity meter [19]. Cation exchange capacity (CEC) was determined using the sodium acetate method as proposed by [19]. 
Sodium adsorption ratio (SAR) was according to [19]. Soluble ions were determined in the saturated soil paste extract according to [17].

\section{RESULT AND DISSECTION}

\section{1 Some soil physical and chemical properties}

Some soil physical and chemical properties investigated are shown in Table $\mathbf{1}$ and fig. 2.The texture class of soil samples under study was varied from loamy sand to clay texture. Sand, silt, and clay content ranged from 28 to 89 , from 4 to 37 and from 7 to $47 \%$, respectively. The bulk density and saturation percentage were ranged from 1.22 to $1.73 \mathrm{~g} / \mathrm{cm}^{3}$ and 16 to $76 \%$ with mean $1.42 \mathrm{~g} / \mathrm{cm}^{3}$ to $52.10 \%$, respectively. Soil $\mathrm{pH}$ values ranged from 7.56 to 8.83 with mean 7.89. The highest value of $\mathrm{pH}$ was found in sample No.8. The high value of $\mathrm{pH}$ may be attributed to the reaction of applied fertilizer material with soil colloids and increased the soluble salts and content of calcium. Also, soil tillage systems lead to an increase of soil $\mathrm{pH}$, base saturation, and extractable phosphorus [25]. [14] he found that the levels of soil $\mathrm{pH}$ in some soils of Upper Egypt ranged from 7.73 to 9.45. Also, [5] found that a $\mathrm{pH}$ range of 6.5 to 7.5 is optimal for plant nutrient availability.

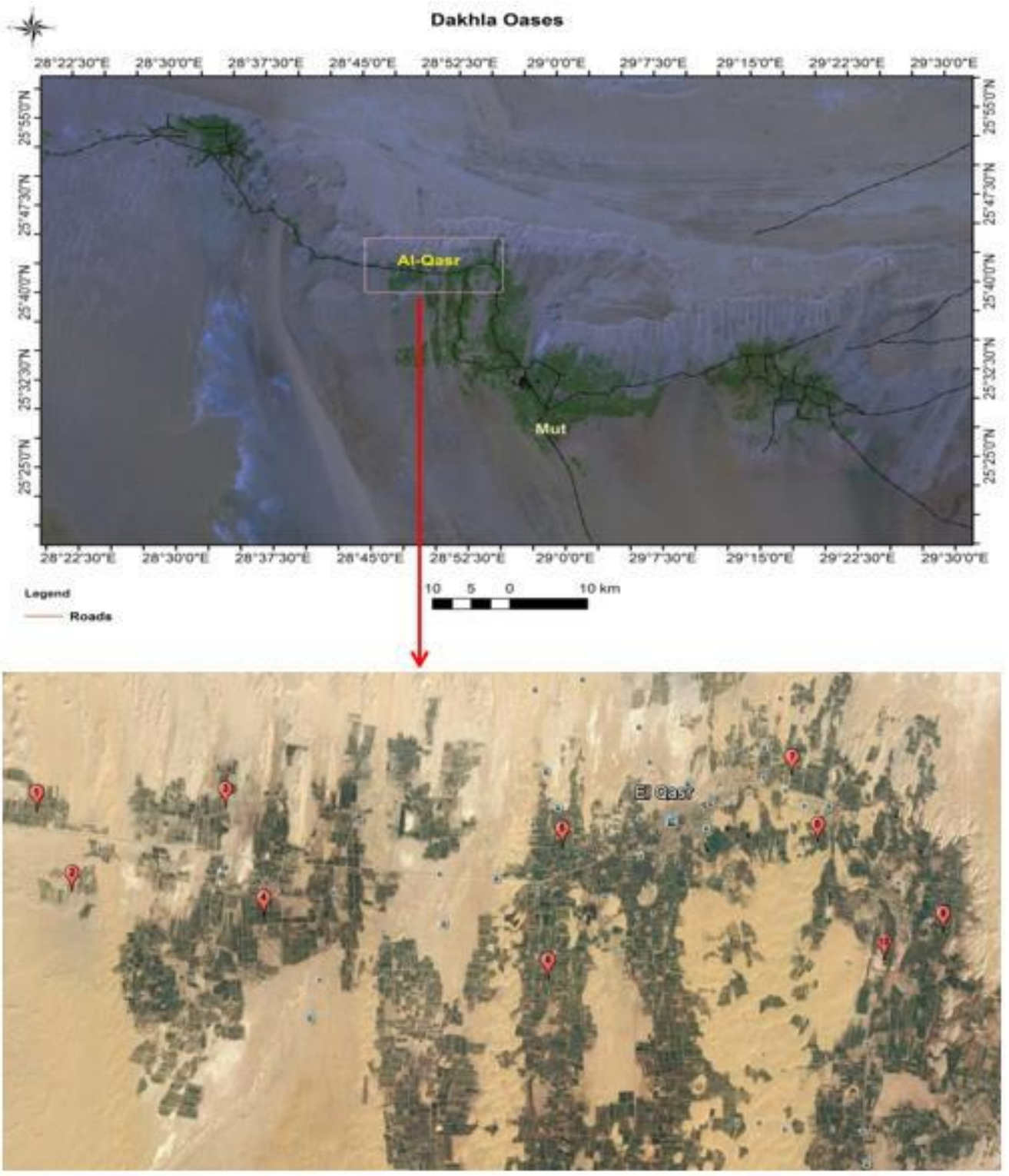

Fig.1: El-Dakhla Oasis map and location of soil sampling points in El-Qasr area. 
Table.1: Some physico- chemical properties of collected soil samples in El-Qasr area.

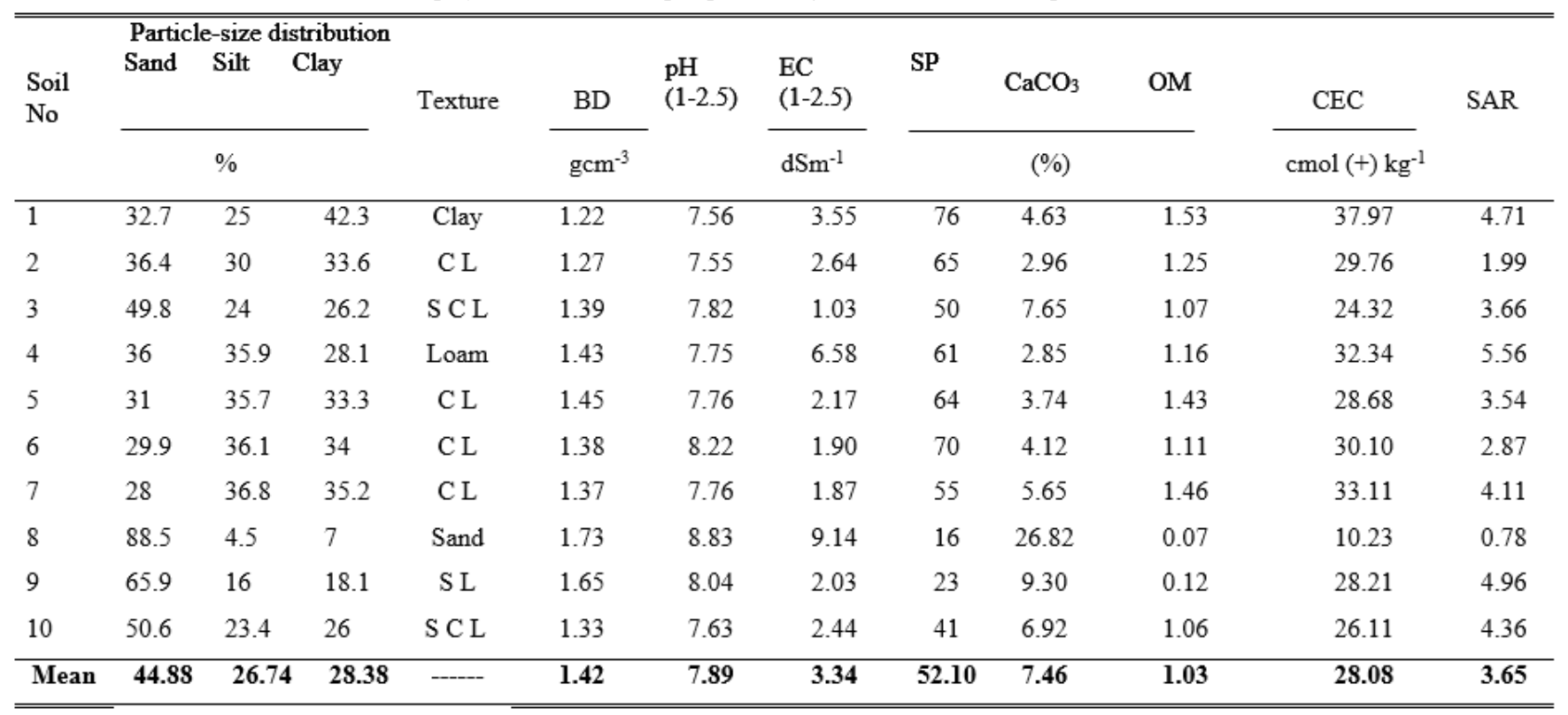

$\mathrm{CL}=$ clay loam, $\mathrm{SCL}=$ sand clay loam, $\mathrm{SL}=$ sandy loam

In the present investigation study the $\mathrm{CaCO}_{3}$ content of the investigated soil samples ranged between 2.85 and 26.82\%. Soil No 8 has the high amount of $\mathrm{CaCO}_{3}$ $(26.82 \%)$. These high amounts of $\mathrm{CaCO}_{3}$ probably due to the high soil salinity or even soil texture [6]. In general, the accumulation of calcium carbonate in the soils depends on the position of the area, evaporation rates and the depth of percolating rainwater [12]. [15] they found that the values of $\mathrm{CaCO}_{3}$ in some soils in Upper Egypt ranged from 0.15 to $49.00 \%$. Also, the results in Table 2 indicate that the content of $\mathrm{OM}$ of the studied soil samples ranged from 0.07 to $1.53 \%$ with a mean value of $1.03 \%$. The lower OM content is related to the coarse soil texture, while the higher one is attached to the fine and medium soil texture. This result is an agreement with those obtained by [12] whom found that soil organic matter content in El-Dakhla Oasis (GarbEl-Mawhob area) was very low and ranged from 0.05 to $1.41 \%$. The cation exchange capacity (CEC) was varied from 10.23 to 37.97 cmol (+) $\mathrm{kg}^{-1}$. The high value $\left(37.97 \mathrm{cmol}(+) \mathrm{kg}^{-1}\right)$ of CEC may be due to the high of organic matter and clay content. This result agrees with those obtained by [26], [21]) and [7] they reported that both clay content and organic matter considered as a source of nutrients by attracting cations and provide more exchange sites to get the cations adsorbed on it; so, soils that have a large amount of clay or organic matter have higher exchange capacities than sandy soils, which are usually low in clay content and organic matter. Also, the low values of CEC may be attributed to the effect of soil tillage that led to the reduction of soil organic matter [25]. The values of SAR ranged from 0.78 to 5.56 (Table 2. and figure 3), SAR values can be indicating that the majority of soils have less than 8 , the non-sodic soils cover about $77 \%$ of the soils. 

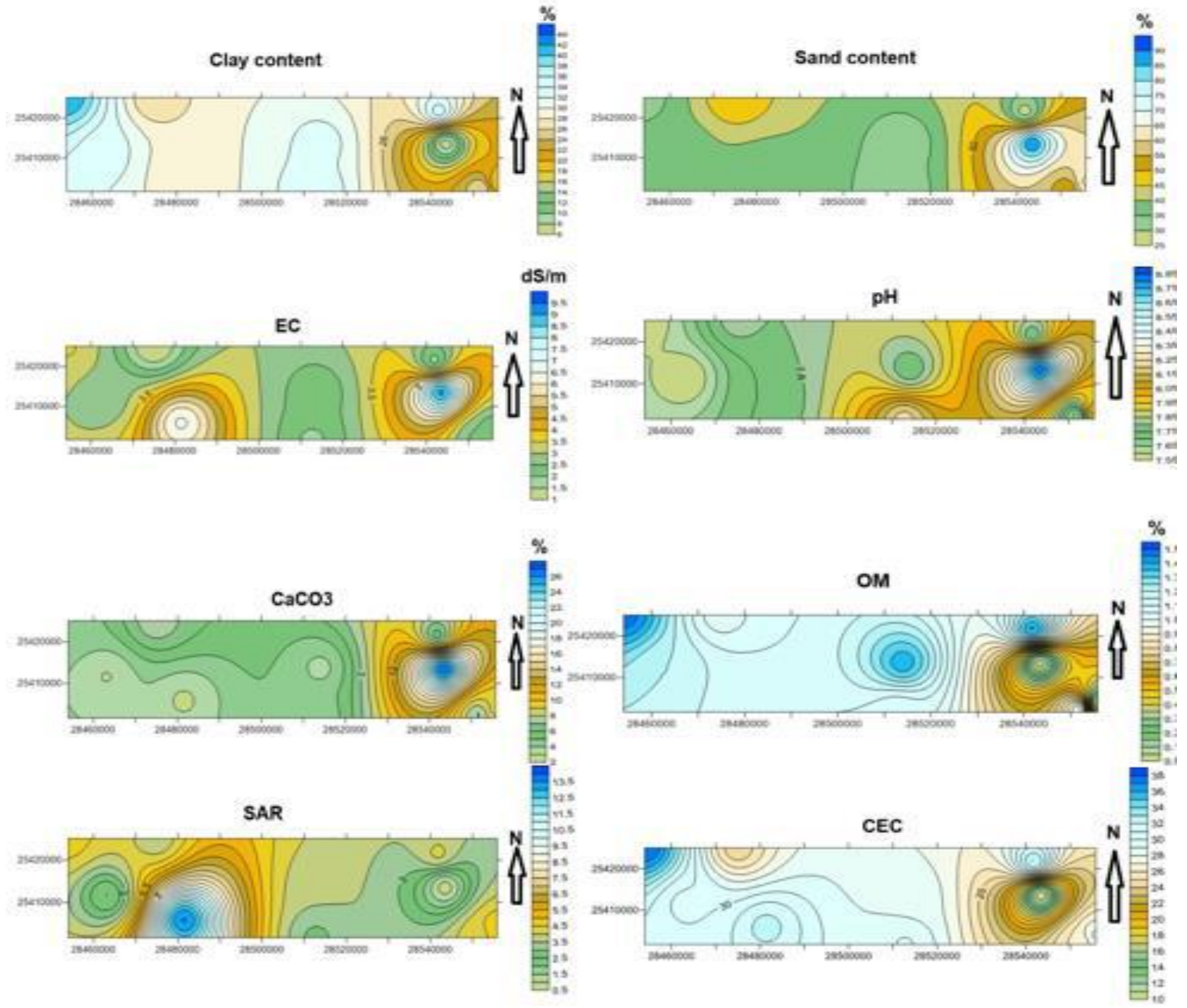

Fig.2: The distribution maps of some physical and chemical properties in El-Qasr area soils.

\section{2 Availability of macro-micronutrients}

The results of the available NPK in the studied soils are shown in Table 3 and Figure 3. The values of macro elements were ranged from 70.31 to $170.22 \mathrm{mg} / \mathrm{kg}$ for $\mathrm{N}$ with a mean value of $99.37 \mathrm{mg} / \mathrm{kg}$, from 14.33 to $52.71 \mathrm{mg} / \mathrm{kg}$ for $\mathrm{P}$ with a mean value of $31.32 \mathrm{mg} / \mathrm{kg}$, and from 82.36 to $240.04 \mathrm{mg} / \mathrm{kg}$ for $\mathrm{K}$ with a mean value of $121.93 \mathrm{mg} / \mathrm{kg}$. The highest level of available $\mathrm{N}, \mathrm{P}$, and $\mathrm{K}$ was recorded in soil sample No. 5. This may be attributed to the addition of plants residual and organic fertilizers that provide substrate for microbial growth, and subsequent microbial activity [28]. In sandy calcareous soils, the content of extractable soil $\mathrm{P}$ was $4.50 \mathrm{mgkg}^{-1}$ reported by [10]. On the other hand, [1] demonstrated that the extractable soil $\mathrm{P}$ ranged from $0.10-0.35 \mathrm{mgkg}^{-1}$ in some different soils of Egypt. The mean levels of the extractable $\mathrm{P}$ in the loamy soils were always higher than those of sandy or clay soils. The value of available potassium ranged from 0.1 to $2.34 \mathrm{mg} \mathrm{kg}^{-1}$.
The excess in potassium may lead to plants will exhibit typical $\mathrm{Mg}$, and possibly Ca deficiency symptom due to a cation imbalance [24]. DTPA-extractable of micronutrients in the studied soils was shown in Table 3 and Fig. 3. The values of these elements ranged from 21.54 to $33.54,14.76$ to $24.87,2.12$ to 4.23 , and 0.31 to $0.72 \mathrm{mgkg}^{-1}$ with a mean value of $27.39,18.38,0.48$ and $3.48 \mathrm{mg} / \mathrm{kg}$ for $\mathrm{Fe}, \mathrm{Mn}, \mathrm{Cu}$, and $\mathrm{Zn}$, respectively.

Generally, the highest levels of micronutrients were showed in soil samples No.8, respectively. In El-Dakhla oasis soils, [4] found the available $\mathrm{Fe}, \mathrm{Mn}, \mathrm{Cu}$ and $\mathrm{Zn}$ content range from 250 to $396,0.21$ to $7.4,0.15$ to 0.43 0.77 , and from 0.15 to $0.43-0.77 \mathrm{mgkg}^{-1}$, respectively. [20] found that the Fe extracted by DTPA ranged between 1.20 to $28.60 \mathrm{mgkg}^{-1}$ in some soils of middle and Upper Egypt. Also, they found that the DTPA-extractable Mn ranged from 1.10 to $57.40 \mathrm{mgkg}^{-1}$. [18] reported that the levels of DTPA-extractable $\mathrm{Cu}$ varied from 0.17 to 4.88 $\mathrm{mgkg}^{-1}$ in Sohag soils, Egypt. Generally, the availability 
of all nutrients in soil remarkably improved by the application of gypsum, which creates a more favorable environment in soil and maintain elements in a more available form due to reclamation effect [9] and [27].

Table.2: Available macro and micronutrients $\left(\mathrm{mgkg}^{-1}\right)$ of the collected soil samples in El-qasr area.

\begin{tabular}{llllllll}
\hline \hline $\begin{array}{l}\text { Soil } \\
\text { No }\end{array}$ & \multicolumn{2}{l}{ Available macronutrients } & \multicolumn{5}{c}{ DTPA-extractable micronutrients } \\
& $\mathbf{N}$ & $\mathbf{P}$ & $\mathbf{K}$ & $\mathbf{F e}$ & $\mathbf{M n}$ & $\mathbf{C u}$ & $\mathbf{Z n}$ \\
\hline 1 & 140.36 & 44.42 & 133.12 & 29.65 & 14.78 & 3.22 & 0.44 \\
2 & 110.32 & 36.31 & 127.11 & 29.87 & 13.43 & 3.22 & 0.48 \\
3 & 70.31 & 28.41 & 116.52 & 13.32 & 14.76 & 2.12 & 0.31 \\
4 & 80.16 & 38.35 & 97.34 & 17.43 & 18.32 & 3.65 & 0.52 \\
5 & 170.22 & 52.71 & 243.04 & 31.55 & 12.43 & 4.20 & 0.63 \\
6 & 104.21 & 26.34 & 112.54 & 33.54 & 22.54 & 3.97 & 0.39 \\
7 & 99.12 & 24.65 & 105.67 & 29.67 & 21.64 & 3.78 & 0.44 \\
8 & 55.71 & 14.33 & 82.36 & 36.75 & 24.42 & 4.23 & 0.72 \\
9 & 55.61 & 21.78 & 92.13 & 21.54 & 20.65 & 4.12 & 0.41 \\
10 & 107.64 & 25.91 & 109.44 & 30.54 & 20.87 & 2.23 & 0.43 \\
\hline Mean & $\mathbf{9 9 . 3 7}$ & $\mathbf{3 1 . 3 2}$ & $\mathbf{1 2 1 . 9 3}$ & $\mathbf{2 7 . 3 9}$ & $\mathbf{1 8 . 3 7}$ & $\mathbf{3 . 4 8}$ & $\mathbf{0 . 4 8}$ \\
\hline \hline
\end{tabular}
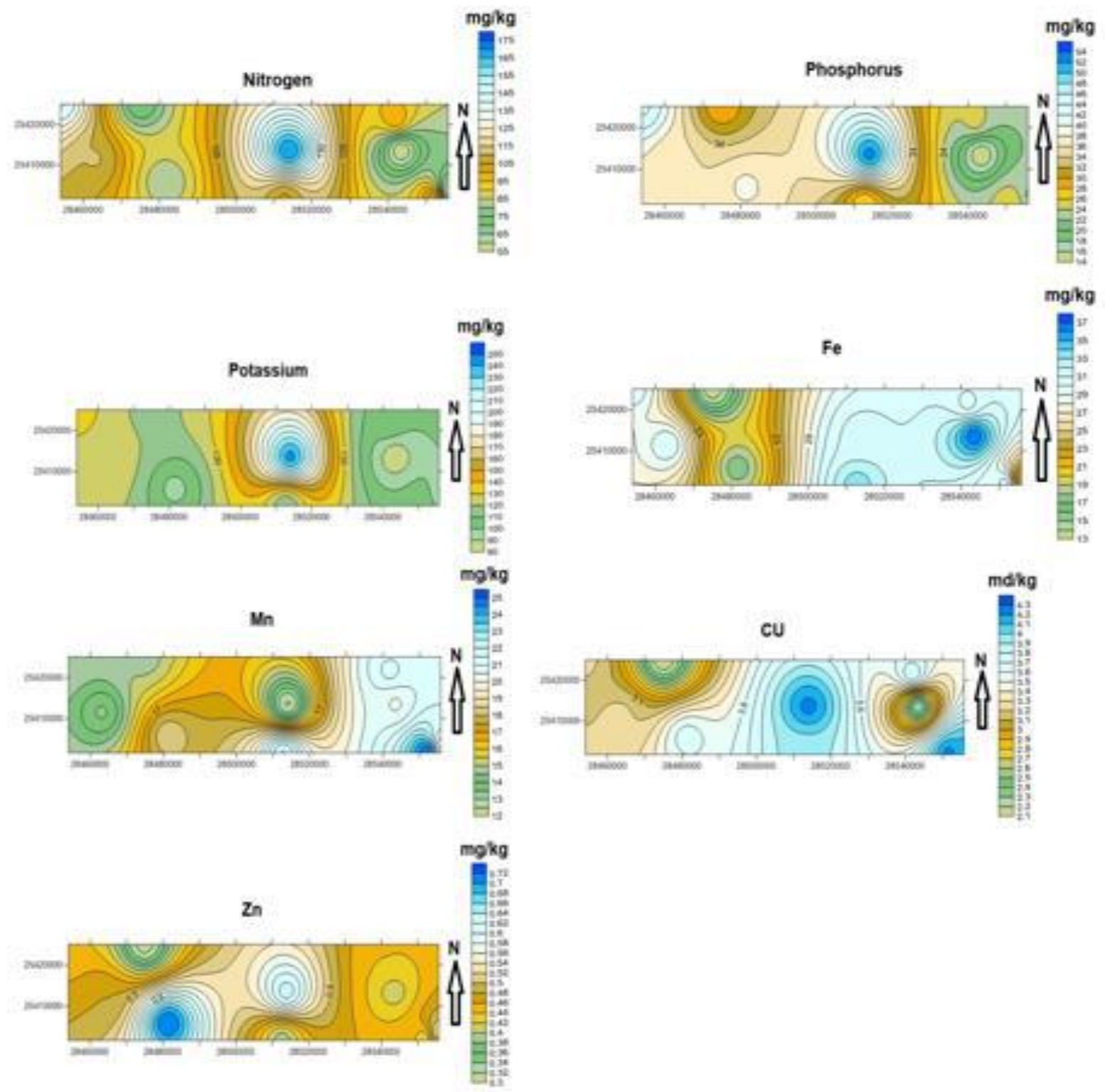

Fig.3: The distribution maps of macro and micronutrients in El-Qasr area soils. 
3. 3 Linear correlation coefficients amonge macromicronutrients and some soil physico- chemical properties in El-Qasr area.

The correlation coefficient in Table 4 shows that NPK were related positively and significantly relationship with clay, (0.687, 0.625, 0.466 and, respectively), OM (0.728, 0.676, 0.519and, respectively), and CEC (0.415, 0.516, 0.233 and, respectively), while, they negatively correlated with $\mathrm{pH}, \mathrm{EC}, \mathrm{CaCO}_{3}$. This is evident as the proportion of clay in the soil is recognized to positively increase the amount of nutrients in the soil [26]; [3]. Meanwhile, Fe, $\mathrm{Mn}$, and $\mathrm{Cu}$ were positively correlated with $\mathrm{EC}, \mathrm{CaCO}_{3}$, but they negatively correlated with clay, $\mathrm{pH}, \mathrm{OM}, \mathrm{CEC}$, and SAR. Also, SAR was negatively correlated with $\mathrm{K}$, $\mathrm{Fe}, \mathrm{Mn}$, and $\mathrm{Cu}$, while it was positively correlated with $\mathrm{N}$, $\mathrm{P}$ and $\mathrm{Zn}$. As well as $\mathrm{Zn}$ was negatively correlated with clay, $\mathrm{pH}, \mathrm{EC}, \mathrm{OM}$, and $\mathrm{CaCO}_{3}$, while it was positively correlated with CEC and SAR. Generally, the high positive correlations may be attributed to imply that soil properties are influenced by similar climatic and biotic factors that are likely to influence the buildup of nutrients in the soil, while the negative associations mean that the soil properties are not influenced by similar climatic and biotic factors [8].

Table.3: The correlation coefficient among macro and micronutrients and some soil physico-chemical properties in El-Qasr area.

\begin{tabular}{cccccccc}
\hline \hline property & $\mathbf{N}$ & $\mathbf{P}$ & $\mathbf{K}$ & $\mathbf{F e}$ & $\mathbf{M n}$ & $\mathbf{C u}$ & $\mathbf{Z n}$ \\
\hline Clay & 0.687 & 0.625 & 0.466 & -0.059 & -0.487 & -0.157 & -0.055 \\
$\mathbf{p H}$ & -0.489 & -0.611 & -0.349 & -0.402 & -0.655 & -0.510 & -0.138 \\
EC & -0.388 & -0.264 & -0.344 & 0.239 & 0.408 & 0.371 & -0.051 \\
OM & 0.728 & 0.676 & 0.519 & -0.058 & -0.533 & -0.285 & -0.226 \\
CaCO $_{3}$ & -0.548 & -0.666 & -0.389 & 0.343 & 0.556 & 0.237 & -0.171 \\
CEC & 0.415 & 0.516 & 0.233 & -0.314 & -0.349 & -0.051 & 0.275 \\
SAR & 0.006 & 0.260 & -0.008 & -0.644 & -0.102 & -0.182 & 0.394 \\
\hline \hline
\end{tabular}

\section{CONCLUSION}

The soil sample shows the relatively highly alkaline nature and low value of $\mathrm{N}, \mathrm{P}$, and $\mathrm{K}$. The $\mathrm{EC}$ values were in a medium range for most soils but it's high in soil no 4 and 8 . The excess amount of micro nutrient shows a medium range in most study soils. So, recommended that in location point where the soil is deficient in $\mathrm{N}, \mathrm{P}$, and $\mathrm{K}$ which requires addition of more fertilizer and manures to improve their physical and chemical properties and make it suitable plantation and for increasing plant growth and yield production.

\section{REFERENCES}

[1] Abd el-Regal, R.M., A.H. Abd el-Hamied and H.A. Nofal. 1995. Effect of organic and inorganic fertilizers on nutrients availability in waterlogged soils 1. Nitrogen and phosphorus. Annals of Agric. Sc. Moshtohor. 33(4):1615-1629.

[2] Arif B. T., Hikmet Günal, Kamil Sındır and Yüksel Balc1. 2001. Spatial Structure of Available Micronutrient Contents and Their Relationships with Other Soil Characteristics and Corn Yield. Fresenius Environmental Bulletin. PSP. Volume 20 - No 3a.

[3] Aweto A.O., \& Enaruvbe G. O. (2010). Catenary Variation of Soil Properties under Oil Palm Plantation in South Western Nigeria. Ethiopian
Journal of Environmental Studies and Management, 3(1), 1-7. http://dx.doi.org/10.4314/ejesm.v3i1.54389

[4] Botros, S. S.2013. Pedological studies of soils between West El-Mawhoob and Abo Monqararea Western desert-Egypt. Ph.D. Thesis: Desert Research Center, Cairo, Egypt.

[5] Brady, N.C. and Weil, R.R. 2002. The Nature and Properties of Soils, 13th Ed. Prentice- Hall Inc., New Jersey, USA., 2002, 960.

[6] Chaney, R. and Slonim, S. 1982. Determination of Calcium Carbonate Content in Soils: Geotechnical Properties Behavior and Performance of Calcareous Soils. In: "ASTM STP, Vol: 777. American Society for Testing and Materials" Demars, K. R., Chaney, R. (Eds.), Philadelphia, PP. 3-15.

[7] Chude, V. O., Malgwi, W. B., Amapu, I. Y. and Ano, A. O. (2011). Manual on Soil Fertility Assessment. Federal Fertilizer Department. FAO and National programme on Food security, Abuja, Nigeria. 62.

[8] Deekor, T. N.2012. Changes in Soil Properties under Different Land Use Covers in Parts of Odukpani, Cross River State, Nigeria. J. of Env. and Ecology. ISSN 2157-6092. Vol. 3, No. 1

[9] Dhanushkodi, V. and K. Subrahmaniyan, 2012. Soil Management to increase rice yield in salt affected coastal soil. Int. J. Res. Chem. Environ., 2: 1 - 5. 
[10]El-Desok y, M.A. and H.M. Ragheb. 1993. Availability of P in sandy calcareous soils: II. Effects of organic matter and added P. Assiut J. Agric. Sci. 24(1): 137-153.

[11]El-Sankary, M.M. 2002. Geological, sedimentological and radioactivity studies of the Quaternary sediments, ElKharga Depression, Western Desert, Egypt.Unpublished Ph.D. Thesis, Ain Shams Univ., Cairo,Egypt, 241p.

[12]El-Sayed, M. A., Abd El-Aziz, S. H., El-Desoky, A. I. and, Selmy, S. A. H. 2016.Pedomorphic Features and Soil Classification of Gharb El-Mawhob area, ElDakhla Oasis, Western Desert, Egypt. 1 Middle East Journal of Agriculture Research ISSN 2077-4605 Volume : 05 | Issue : 02 | April-June | 2016 Pages: 247-257.

[13]Epstein, E. and A. Bloom. 2005. Mineral nutrition of plants: Principles and perspectives.Sunderland, MA: Sinauer Associates.

[14]Faragallah, M.E.A. 1995. Relative distribution of certain nutrients in soils of the Nile valley-desert interference zone, east of Assiut city. M.Sc. Thesis, Faculty of Agric., Assiut Univ., Egypt.

[15] Ghoneim, M.F., M. Abd El-Razek, G.S. El-Gharably and K. AbdEllah. 1984. Micronutrient status in soils of upper Egypt. 1- Zinc. Assiut J. Agric. Sci. 15(3): 15-26.

[16] HaribhushanAthokpam, ShabirHussainWani, David Kame, Herojit Singh thokpam, JyotsnaNongmaithem, Deepak Kumar, YanglemKenedy Singh, Brajendra Singh, Brajendra Singh Naorem, ThokchomRenuka Devi and Lamalakshmi Devi. 2013. Soil macro- and micro- nutrient status of Senapati district, Manipur (India). African Journal of Agricultural Research. Vol. 8(39), pp. 4932-4936.

[17] Hesse, P.R. 1998. A textbook of soil chemical analysis. CBS Publishers \& Distributors. Delhi, India.

[18] Ibrahim, M.S., A. Abd El-galil and M.M. Kotb. 2001. Total and availability $\mathrm{Fe}, \mathrm{Mn}, \mathrm{Zn}$, and $\mathrm{Cu}$ in some soils of Sohag Governorate and their association with some soil properties. Assiut J. Agric. Sci. 32:71-85.

[19] Jackson, M. L. 1973. Soil Chemical Analysis. Prentice Hall, New Delhi.

[20] Kishk, M.A., M. AbdElrazek and G.S. El-Gharably. 1980. Status of certain micronutrients in some selected soils from Middle and Upper Egypt. Assiut J. Agric. Sci. 11: 197-206.

[21] Maji, A.K., R.G.P. Obi, S. Thayalan and N.J. Walke, 2005. Characteristics and classification of landforms and soils over basaltic terrain in sub-humid tropics of central India. J. Indian Soc. Soil Sci., 53: 154-162.
[22] Mclean, E. O. 1982. Soil pH and Lime Requirement. Part II. In: "Methods of Soil Analysis ", (Ed.): Page, A. L. 2nd Edition, ASA, Monograph, No. 9, Madison, WI, PP. 199-223.

[23] Nelson, D. W. and Sommers, L. E. 1982.Total Carbon, Organic Carbon, and Organic Matter. Part II. In: "Methods of Soil Analysis", (Ed.): Buxton, D. R. 2nd Edition, ASA, Monograph, No. 9, Madison, WI, PP. 539-579.

[24] Nigam G.K., V. K. Pandey, M. P.Tripathi, and Jitendra Sinha.2014. Assessment of Macro and Micro Nutrients of Soil in a Small Agricultural Watershed.International Journal of ChemTech Research. Vol.6, No.7, pp 3658-3664

[25] Paz-Gonzalez, A., S. R. Vieira and Ma .T. Taboada Castro, 2000.The effect of cultivation on the spatial variability of selected properties of an umbric horizon. Geoderma,97: 273-292.

[26] Reid, G. and Dirou, J. (2004). How to Interpret Your Soil Test. [Online] Available: http://www.dpi.nsw.gov.au/agriculture/resources/soil s/testing/interpret.

[27] Sudan, P., R. Mathur, M.P. Chandrawat and S. Jain, 2015. Utilization of Marble slurry to Enhance Soil Fertility and to Protect Environment. Int. J. Pharm Bio Sci. 6(2): $81-84$.

[28] Suge, J.K., M.E. Omunyin and E. N.Omami, 2011. Effect of organic and inorganic sources of fertilizer on growth, yield and fruit quality of eggplant (Solanum Melongena L). Arch. Appl. Sci. Res., 2011, 3 (6):470-479. 